(C) О.А. Зыкина

\title{
МИГРАЦИОННЫЕ ПЛАНЫ ВЫПУСКНИКОВ РОССИЙСКИХ ШКОЛ: РЕГИОНАЛЬНЫЙ АСПЕКТ*
}

\begin{abstract}
Миграчионный фактор может оказывать различное воздействие на сочиально-экономическое развитие территорий в зависимости от конкретньх условий и сложсивихся практик. На примере трех различных субъектов Российской Федерации - Москвы, Калининградской и Кировской областей в статье сделана попытка рассмотреть взаимосвязь миграционной ситуаџии в регионе и миграционных установок молодого поколения. Анализ специфики миграчионных прочессов, проведенный на основе результатов ряда экспертных работ и сведений официальной государственной статистики за последние десять лет, позволяет выделить некоторые характерные направления в передвижении населения в каждом из выбранных регионов. В качестве эмпирических данных были взяты материаль массовых опросов школьников и студентов. Текущий срез мигращионных намерений учашихся стариих классов представлен в контексте региональных особенностей в стратегиях миграции молодежи, что дает возможность оценить потенциальную реализацию их планов в общероссийском масштабе. В иелом можно говорить о вероятном сохранении в ближайшие годы сложивиихся тенденций миграционного поведения молодежи. Все озвученные респондентами установки - на смену своего постоянного места жительства либо, напротив, желании связать жизнь со своим настоящим местопребыванием - соотносятся с данными о реальном перемещении молодых россиян для каждой из территорий.
\end{abstract}

Ключевые слова: учашиеся старших классов; мигращионные планы; региональные особенности миграчионных прочессов; межрегиональная миграчия молодежи; Москва; Калининградская область; Кировская область

Миграционное движение населения является одним из значимых факторов демографического развития территорий. На сегодняшний день Россия является активным участником мировых миграционных процессов. По последним данным Российская Федерация располагается на втором месте после США по суммарному потоку приехавших и выехавших международных мигрантов (IОМ 2020: 26). При этом согласно сведениям официальной государственной статистики, число прибывших в Россию на продолжительный срок иностранных граждан с 1991 года по настоящее время неизменно превышает число выбывших за рубеж россиян (Общие итоги 2020), и сложившийся миграци-

Зыкина Ольга Александровна - младший научный сотрудник, Институт этнологии и антропологии им. Н.Н. Миклухо-Маклая РАН (119991 Москва, Ленинский просп., 32а). Эл.почта: ol_ya_z@mail.ru

* Работа выполнена при финансовой поддержке Российского фонда фундаментальных исследований (грант № 20-59-00014) 
онный прирост вплоть до 2017 года в полной мере компенсировал естественную убыль населения в нашей стране (Численность 2011-2020). Внутрироссийская миграция по масштабам на порядок превосходит миграцию международную, и ее влияние на демографическую ситуацию в стране достаточно существенно (Там же).

Миграционные процессы вносят свои коррективы в изменение не только численности, но и структуры населения отдельно взятой территории за счет имеющихся различий между приезжими и коренными жителями по возрастному, половому, этноконфессиональному, семейному составу. Наряду с этим наличие устойчивых направлений миграции зачастую способствует перераспределению трудовых ресурсов между странами, регионами, городами, районами (Мкртчян 2014). Причиной этому служат, в частности, активные перемещения молодых людей ${ }^{1}$, которые составляют среди мигрантов наиболее многочисленную группу. Как следует из статистических материалов по нашей стране за последние годы, около половины от общего числа мигрантов как международных, так и переселявшихся в пределах России - находились в возрасте 14-35 лет. Кроме того, первый и наиболее масштабный пик миграции в России приходится на когорту 17-19 лет (Численность 2011-2020). В значительной степени такое миграционное поведение в этом возрасте объясняется потребностью в получении высшего образования².

В контексте влияния миграции на демографические и социально-экономические процессы в регионах Российской Федерации и активного участия в них молодого поколения вопросы, связанные с изучением миграционных установок современной молодежи, являются предметом пристального внимания ученых. Однако, большинство исследований в этой сфере охватывает в первую очередь студентов (Варшавская, Чудиновских 2014; Симонян 2018; Фадеева, Софронов: 2018 и др.), анализ миграционных намерений школьников проводится относительно редко (Флоринская, Рощина 2008; Флоринская 2017; Мкртчян 2017). Поскольку самая массовая волна переездов связана с переходом учащихся на следующую ступень образования и именно на уровне старших классов школы часто осуществляется первый выбор последующего места проживания, миграционные планы старшеклассников могут в дальнейшем существенно влиять на изменения структуры населения в регионе в случае их реализации. В настоящей работе сделана попытка не только показать текущий срез миграционных намерений учащихся старших

${ }^{1}$ В действующих Основах государственной молодежной политики Российской Федерации на период до 2025 года к молодежи относят людей от 14 до 30 лет, а в некоторых случаях, определенных нормативными правовыми актами РФ и субъектов РФ, - до 35 и более лет (Основы 2014: 2). Новая редакция данного законопроекта, которая сейчас находится на этапе обсуждения, предусматривает увеличение предельного возраста молодых людей до 35 лет (ТАСС 15 июля 2020). С учетом предполагаемых изменений терминологии в нормативно-правовой документации в настоящей работе к молодому населению отнесены лица в возрасте от 14 до 35 лет.

${ }^{2}$ Как показывает ряд исследований, в большинстве случаев начало миграционной биографии выпадает на окончание школы и выбор нового места обучения (см., напр. Семенова 2017: 104-105; Мкртчян 2017: 227; Карачурина, Мкртчян 2017: 102-103), и студенческая миграция является одной из трех наиболее значимых компонент, необходимых для анализа и прогноза миграционных процессов в России (Ермаков, Никитина 2015: 27). Следует также отметить, что если прежде массовый переезд осуществлялся молодыми людьми в первую очередь в возрасте 17-19 лет (Каиницкий, Мкртчян, Лешуков 2016: 173), то с 2014 года начинают все более активно менять регион пребывания 20-24-летние; в 2018 году эта возрастная когорта и вовсе становится ведущей в межрегиональной внутрироссийской миграции (Численность 2011-2020). Вероятно, здесь сыграл свою роль окончательный переход на Болонскую систему образования в России, предусматривающий введение двух ступеней высшего образования - возник новый этап жизни человека, когда территориальное перемещение оказывается не только возможным, но зачастую необходимым. 
классов, но и рассмотреть региональные особенности в стратегиях поведения молодежи на примере трех различных субъектов Российской Федерации - Москвы, Калининградской и Кировской областей, - что представляется актуальным также ввиду небольшого числа сравнительных исследований по данной проблематике.

\section{Миграционные планы старшеклассников столичного региона России: Москва}

Москва как столица и как один из крупнейших мегаполисов мира представляет собой особую городскую агломерацию России, предлагающую широкие возможности для получения образования, трудоустройства, организации досуга. Москва является безусловным центром притяжения мигрантов со всей страны и из-за рубежа. Миграция стала главным фактором увеличения численности населения города, по меньшей мере, с 1960-х годов. Миграционный прирост превосходил естественный в 1960-е гг. в 1,2 раза, в 1970-е и 1980-е гг. - в 3 раза, а с 1989 вплоть до 2011 гг. миграция была единственным источником роста населения в Москве и компенсировала установившуюся естественную убыль (Зайончковская, Иоффе 2013). В последнее десятилетие, с 2011 г., миграционный прирост превышает естественный ${ }^{1}$ в среднем в 5 раз (Москва 2014: 9, 12; Численность 2012-2016; Москва 2020: 11-14). Если же рассматривать объемы миграционных потоков на территории столицы в масштабах России, то участие Москвы в общей миграции сопоставимо с долей ее населения в составе страны и держится на уровне $7-11 \%{ }^{2}$.

По показателю интенсивности миграционного прироста ${ }^{3}$ Москва занимает ведущие позиции, но, тем не менее, уступает ряду регионов, в частности, многим городам Московской области. Соседствующие со столицей города фактически срослись с ней и выполняют роль ее спальных районов, а потому заселяются весьма активно (Мкртчян 2014: 390). Однако суммирование данных по Москве и Московской области уже выводит столичный регион в тройку лидеров среди всех субъектов Российской Федерации по темпам увеличения численности своих жителей за счет миграции. Более детальный анализ распределения мигрантов по территории Москвы, показывает, что она занимает первое место в России по скорости миграционного притока сельского населения (Численность 2020). В условиях Москвы сельские поселения могут быть востребованными и в качестве элитного частного жилья, и, напротив, в случае поиска относительно недорогих вариантов проживания (Мкртчян 2015: 110). Отличительной особенностью столицы может также считаться выраженная зависимость интенсивности миграционного прироста от экономической ситуации в стране, что хорошо видно по данным за 1991-1993 гг. (Зайончковская, Иоффе 2013), а за последнее десятилетие - по материалам за 2016 и 2019 гг. (Численность 2011-2020). В эти периоды зна-

${ }^{1}$ Естественный прирост населения в Москве, наблюдающийся в последние годы, также может быть в определенной степени связан с постоянным миграционным приростом. Согласно последней переписи населения 2010 г. более 40\% женщин в возрасте 17-39 лет, живущих в Москве в 2010 г., не являлись уроженками столицы, соответственно можно говорить о существенном вкладе мигрантов в увеличение рождаемости в данном регионе (Мкртчян, Карачурина 2013: 106).

2 Доля Москвы в общей межрегиональной миграции по России равна 7-11 \%, где 7\% - в среднем за последние десять лет по количеству выбывших за пределы региона, $11 \%$ - по числу прибывших. В общей международной миграции на территории страны участие Москвы составляет порядка 5-6\%, где 5\% в среднем за последние десять лет по количеству новых жителей региона, $6 \%$ - по числу выехавших за рубеж граждан (Численность 2011-2020).

${ }^{3}$ Более подробно о зависимости миграционного прироста в Московском столичном регионе от удаленности территорий от Москвы см. (Мкртчян 2015). 
чения миграционного прироста для Москвы сильно снижаются в пользу Московской области и ряда региональных центров европейской части нашей страны. Еще одной характерной чертой Москвы является наличие гораздо меньшего, чем в других крупных городах России, миграционного оттока. На данный момент в столице наблюдается повышенная доля старожилов (62\%), мигранты с личным опытом переезда сейчас составляют сравнительно небольшое меньшинство $-11 \%{ }^{1}$.

При всей важности официальных статистических сведений для описания миграционного движения населения многие исследователи подчеркивают недостаточность этих данных для адекватного представления о миграционных потоках в России и, в том числе, в столичном регионе. В частности, в ходе оценки только $1 / 3$ трудовой миграции по Москве было выявлено, что количество официально принятых на работу трудовых мигрантов в 11 раз больше числа трудовых мигрантов, переехавших в город на постоянное место жительства. Кроме того, значительная часть временных трудовых мигрантов, нанятых Москвой, проживает на территории области, из-за более дешевой аренды жилья. Таким образом действительный объем новых москвичей для столицы оказывается несколько большим (в пределах 1 млн), чем зарегистрировано (Зайончковская, Иоффе 2013). В равной степени отмечается «невидимость» для статистики реального выезда из Москвы той части ее жителей, которая сохраняет постоянную регистрацию в городе с целью получения социальной поддержки на более высоком уровне по сравнению с другими регионами России, например, региональных доплат к пенсии (Мкртчян 2015: 110-111).

Москва - один из крупнейших в мире образовательных центров, который ежегодно привлекает большое число учебных мигрантов. Максимальный прирост московского населения за счет миграции приходится на возраст 15-19 лет, что дополнительно поддерживается размещением на ее территории студенческих общежитий. В то же время, в отличие от рядовых региональных столиц, в Москве не менее силен приток 20-29-летних, и по группе 30-39-летних он все еще очень значим (Мкртчян 2014: 394). Анализ возрастного профиля миграции за последние десять лет показал, что среди приезжих москвичей доля лиц в трудоспособных возрастах по отношению к общему числу мигрантов выше, чем в среднем по России. Впрочем, в последние четыре года распределение по возрастной структуре новых столичных жителей несколько изменилось из-за резкого увеличения категории пожилых людей². В целом, как можно видеть, миграция способствует «омоложению» населения региона.

\footnotetext{
${ }^{1}$ В среднем по крупным городам России миграционный опыт жителей заметно отличается от московского - доля старожилов достигает $38-40 \%$; число новых горожан, осуществивших переезд во взрослом возрасте, составляет 26-28\% (Гориков 2018: 122, 125).

${ }^{2}$ В России, как и по всему миру (IOM 2020: 26), в миграционные процессы вовлечены в первую очередь люди трудоспособного возраста, что во многом определяется необходимостью серьезных, в том числе финансовых, вложений, наличием большого числа рисков и длительным сроком потенциальной окупаемости переезда. Согласно данным по ежегодному миграционному приросту в Москве соотношение возрастных категорий за последние десять лет выглядит следующим образом: лица моложе трудоспособного возраста от общего числа приезжих в среднем за 2010-2014 гг. составляли 7\% и в среднем за 2015-2019 гг. - 12\%; мигранты в трудоспособных возрастах $-84 \%$ и $74 \%$ соответственно; люди старше трудоспособного возраста - $9 \%$ и $14 \%$. Если суммировать сведения о межрегиональных и межстрановых перемещениях в пределах России за это же время, то распределение по возрасту их участников будет таким: лица моложе трудоспособного возраста от общего числа переселенцев в среднем за 2010-2014 гг. составляли 13\% и в среднем за 20152019 гг. - 17\%; мигранты в трудоспособных возрастах $-76 \%$ и $72 \%$ соответственно; люди старше трудоспособного возраста - 11\% в среднем за все годы (Численность 2011-2020).
} 
В рамках настоящей работы рассмотрим, каким образом соотносится непрерывный поток мигрантов в Москву с миграционными планами самих москвичей. В качестве основных эмпирических данных были использованы материалы массового опроса и глубинных интервью, которые собраны автором в ходе сравнительного исследования в 2018-2019 гг. ${ }^{1}$ В анкетировании приняли участие 148 школьников 9-10 классов из 6 учебных заведений, расположенных в Северном, Северо-Восточном, Юго-Западном, Западном и Восточном административных округах города Москвы.

В ходе опроса респондентам предлагалось ответить на вопрос о своих миграционных намерениях либо, напротив, желании связать свою дальнейшую жизнь с регионом текущего местопребывания. Готовы переехать на постоянное место жительства в другую страну $32 \%$ школьников, в другой регион России - 7\%. Следует отметить, что девушки настроены на зарубежную миграцию несколько больше, чем юноши (36\% против 28\% соответственно). Кроме того, еще около трети подростков затруднились с ответом на этот вопрос, и, очевидно, могут ситуативно выстроить свою жизненную траекторию вне России. Только $22 \%$ опрошенных старшеклассников хотели бы остаться в Москве. В ряде случаев был задействован вариант «другое», в котором учащиеся чаще всего определяли зависимость решения о миграции от конкретных жизненных обстоятельств либо озвучивали желание уехать за границу лишь на некоторое время².

Таким образом, Москва является одним из самых привлекательных для мигрантов городов России. Наблюдается устойчивый прирост населения за счет миграции при существенно более низком оттоке, чем в других крупных региональных центрах страны. В условиях Москвы в результате притока лиц преимущественно в молодых и трудоспособных возрастах текущий демографический рост способствует экономическому. Вместе с тем, фактически более двух третей молодых москвичей не уверены в своей готовности продолжать жизнь в Москве и не рассматривает столицу как перспективное место для своего развития. Каждый третий из опрошенных старшеклассников заявлял о своем намерении переехать из России в другую страну на постоянное место жительства.

${ }^{1}$ В 2018-2019 гг. в рамках изучения российской идентичности в представлении молодежи был проведен опрос среди учащихся школ и вузов Москвы и Кировской области. В общей сложности в исследовании приняли участие более 500 студентов и около 400 старшеклассников. Итоговая выборочная совокупность по школьной группе включает 148 анкет по Москве и 156 анкет по Кировской области; из них 50\% заполнены девушками и 50\% - юношами; профильность обучения для школьников не квотировалась. По студенческой группе общая выборка для Москвы составляет 108 анкет, из них 51 (47\%) заполнены юношами и 57 (53\%) - девушками; по социогуманитарному профилю обучаются 50\% респондентов, по инженерному и естественно-научному - 50\%. Были опрошены студенты МГУ им. М.В. Ломоносова, МГМУ им. Сеченова, ГАУГН, НИУ ВШЭ, МПГУ, НИУ МГСУ, РХТУ им. Д.И. Менделеева. Выборочная совокупность по Кировской области построена на основе опроса учащихся ВятГУ и КирГМУ и включает 300 анкет: 131 (44\%) из них выполнены юношами и 169 (56\%) девушками; социогуманитарное и естественно-научное направления обучения представлены в равных долях. Все выборки среди школьников и студентов могут считаться сбалансированными; на отдельных этапах все они формировались по принципу случайного отбора.

${ }^{2}$ В студенческой группе распределение ответов на этот же вопрос выглядит следующим образом: хотели бы переехать на постоянное место жительства в другую страну $28 \%$ респондентов и в другой регион России - 6\%; затруднились с ответом - 27\% учащихся; планируют остаться в Москве $27 \%$; воспользовались вариантом «другое» - 13\% опрошенных. 


\section{Миграционные планы старшеклассников приграничного региона России: Калининградская область}

Приграничное и приморское геополитическое положение Калининградской области, с одной стороны, определяет особое значение данного региона в процессах коммуникации России со странами Западной Европы и создает необходимые условия для выстраивания конструктивного международного взаимодействия, в том числе на личностном уровне в рамках межкультурного диалога. С другой стороны, крайнее западное и эксклавное месторасположение области и ее роль российского форпоста в Европе становятся основой для формирования в некоторой степени замкнутого сообщества с присущими ему оригинальными свойствами. Миграционное движение населения в этой ситуации оказывается одновременно и важным критерием демографической безопасности региона, и источником стабильного либо неустойчивого его развития в зависимости от значений сальдо миграции.

Калининградская область является одним из наиболее привлекательных для переезда регионов нашей страны и в последние годы по ежегодному миграционному притоку населения на 1000 человек входит в число пяти самых успешных субъектов Российской Федерации, опережая по данному параметру даже Москву (Численность 2011-2020). Миграционный прирост характерен для Калининградской области практически за весь период ее существования, при этом коэффициент миграционного прироста здесь был выше, чем в среднем по России ${ }^{1}$. Особенно высоким он оказался в 1990-1998 гг, когда в область прибыло много мигрантов из Прибалтики и Закавказья. В последующем среди прибывающих из-за рубежа стали преобладать русскоязычные выходцы из Казахстана и Средней Азии (Федоров 2017: 9). В целом, стабильный миграционный прирост в Калининградской области во многом определяется наличием активного обмена населением с зарубежными странами르, поскольку суммарно за последние десять лет он на $60 \%$ сформирован за счет разницы между числом приехавших иностранных граждан и количеством россиян, выехавших за

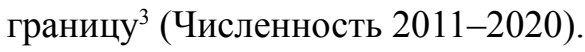

Сопоставление миграционных процессов на Северо-Западе России и в странах Балтии (Карачурина, Мкртчян 2014), а также сравнительное исследование по приморским регионам Западного порубежья России (Лялина 2019) позволяют говорить

${ }^{1}$ Если ориентироваться на результаты одного из специальных исследований, данные по миграционному приросту в последние десять лет по Калининградской области могут быть чуть завышены в связи с не вполне корректным учетом спецконтингентов. Всероссийская перепись для военнослужащих по призыву в 2010 году осуществлялась по месту дислокации воинских частей, а не по месту призыва, в отличие от 2002 года, что в отдельных городах и районах привело к искажению численности контингентов молодежи. Послепересчета и снятия этой диспропорции по нескольким административнотерриториальным единицам Калининградской области было выявлено не увеличение, а снижение общего числа молодых людей (Карачурина, Мкртчян 2014: 73-74). Представленные расчеты влекут за собой возможные изменения и по числу мигрантов в молодых возрастах.

${ }^{2}$ Более подробно о специфике международной миграции в Калининградской области в постсоветское время см.: Емельянова 2010; Зимовина 2014.

${ }^{3}$ Тесные миграционные связи с соседними государствами являются отличительной чертой приграничных субъектов Российской Федерации (Лялина 2019). Высокий вклад международного компонента в миграционное движение населения Калининградской области подтверждает эту тенденцию. По внутренним регионам России доля международных переселений от общего числа миграций существенно ниже: для Москвы этот показатель равен только 14\%; по Кировской области сальдо международной миграции (положительное) не превышает 13\% от численного значения общего миграционного оттока населения в области (Численность 2011-2020). 
о Калининградской области как о регионе с относительно благоприятной миграционной ситуацией. Постоянный миграционный прирост в области, с одной стороны, суммарно компенсирует естественную убыль населения, которая наблюдается в 1992-2019 годы, с другой - способствует «омоложению» возрастной структуры населения, так как среди приезжих большой процент составляют молодые люди (Численность 2011-2020). Однако, здесь стоит добавить, что в Калининградскую область переезжает немало и пожилых людей: если в среднем по России доля лиц старше трудоспособного возраста равна $11 \%$ от общего числа мигрантов, то для Калининградской области этот же показатель почти вдвое выше - 19-20 \% ${ }^{1}$.

Следует отметить несколько важных особенностей Калининградской области в плане трудовой миграции как наиболее крупного и экономически значимого миграционного потока. В условиях эксклавного положения в области более активно привлекается иностранная рабочая сила, нежели трудящиеся-мигранты из других регионов России (Федоров 2019: 190). Кроме того, высока доля трудовых мигрантов не только из центральноазиатских республик, что свойственно в общем практически для всех российских регионов, но также и из приграничной Беларуси (Там же: 188). Одновременно с большим числом прибывающих в поисках работы новых жителей в Калининградской области фиксируется повышенный отток российских граждан за рубеж, главным образом для работы в судоходстве и на промышленных предприятиях, связанных с морским рыболовством и переработкой рыбы. На Калининградскую область приходится более $17 \%$ всех выезжающих на заработки за границу россиян. Еще бо́льшую долю демонстрирует только Краснодарский край - 23,5\%. В конечном счете в Калининградской области при общем миграционном приросте населения сальдо по трудовой миграции оказывается практически нулевым (Там же: 186).

В целом по ключевым миграционным показателям Калининградская область может считаться одним из наиболее благополучных регионов России. На фоне средней ситуации по стране и в сравнении с географически близкими территориями миграционная обстановка в области оценивается скорее положительно. Приграничное расположение региона и интенсивные трансграничные перемещения его жителей в значительной степени определяют высокую мобильность населения Калининградской области и обеспечивают бо́льшую часть установившегося миграционного прироста. В то же время более детальное изучение вопроса показывает ряд существующих сложностей и противоречий демографического развития региона в связи с миграцией. В частности, здесь отмечаются неоднозначное влияние трудовой миграции и даже имеющий место отрицательный отбор ${ }^{2}$.

В таких условиях, когда процесс накопления человеческого капитала подвержен воздействию многих факторов и может иметь различный исход, представление о миграционных намерениях молодого поколения видится необходимым. Исследований по данной теме на материалах Калининградской области относительно мало. В рамках текущей работы остановимся подробнее на результатах одного из них, поскольку оно охватывает именно школьную группу.

\footnotetext{
${ }^{1}$ Доля мигрантов старше трудоспособного возраста по Калининградской области в среднем в 20102014 гг. равна 20\%; в 2015-2019 гг. - 19\% (Численность 2011-2020).

2 В частности, говорится о том, что новые калининградцы чаще пополняют ряды потребителей городских благ, тогда как та часть городского сообщества, которая ориентирована на участие в их производстве, сокращается (Вендина 2016: 13).
} 
В 2014 г. было проведено анкетирование среди учащихся старших классов Калининградской области, всего было опрошено 1172 ученика. Опросный лист включал несколько тематических блоков. Главный акцент был сделан на вопросах, связанных с особенностями формирования идентичностей в специфических условиях области, и на соотношении общероссийского, регионального и этнического компонентов в самосознании подростков (Григорьева, Мартынова 2017: 5). Среди прочего учащихся спрашивали о желаемом месте жительства и предполагаемой миграции. На вопрос «Где бы вам хотелось бы жить, если бы это зависело только от Вашего желания?» ответили все 1172 респондента, большинство из них дали несколько вариантов ответа. Почти каждый третий (29\%) хотел бы жить в другой стране, но около 14\% опрошенных рассматривают зарубежные страны как альтернативу Москве, Санкт-Петербургу, Калининграду и Калининградской области. При этом был назван широкий перечень зарубежных стран, в которых хотелось бы жить: США, Англия, Германия, Азербайджан, Южная Корея, Франция, Италия, Австралия, Канада, Япония, Швейцария и другие. Вместе с тем, 39\% (457 чел.) опрошенных старшеклассников рассматривают Калининград и Калининградскую область как желаемые места их жительства. В их числе 12\% (162 чел.) не исключают вместе с Калининградом и областью иные варианты: Санкт-Петербург, Москву, другие города России, другие страны (Там же: 105). Суммируя, можно представить полученные данные следующим образом: не планируют уезжать из Калининградской области $27 \%$ респондентов; готовы в равной степени обосноваться как в Калининграде, так и в других городах России и мира - 12\%; ориентированы на проживание за границей, но допускают возможность остаться в России $-14 \%$; без сомнений хотели бы жить в другой стране $-15 \%{ }^{1}$.

Высокая интенсивность миграций молодых людей в связи с поступлением в вузы определяет важность сведений о выбранном городе или стране для продолжения обучения в ходе оценки потенциальных пространственных перемещений молодежи. В том же исследовании 2014 г. на вопрос о желаемом месторасположении образовательного учреждения следующей ступени отреагировали 99\% (1165 чел.) из всех опрошенных

\footnotetext{
${ }^{1}$ Интересно сопоставить эти данные с результатами массовых социологических опросов студенческой молодежи в 2013 и в 2016 гг. В 2013 г. о настроенности на эмиграцию заявляли 63\% опрошенных студентов и уже 59\% - в 2016 г. (Симонян 2017: 321-322). По другому исследованию 2016 г. на близкий по смыслу вопрос о желании переехать за рубеж на постоянное место жительства было получено следующее распределение ответов: вариант «меня это не привлекает» выбрали 19,4\% опрошенных; обязательно воспользовались бы такой возможностью - 54,3\%; затруднились с ответом 26,3\% (Винокуров 2017: 70). Как можно видеть на примере последнего из опросов, при заполнении анкеты вариант переезда в другой регион России в этих исследованиях, судя по всему, не предлагался. Возможно, именно такая сосредоточенность опросного листа на внешней миграции приводит к высокой доле потенциальных эмигрантов от общего числа респондентов, поскольку по двум другим категориям значения сравнимы с результатами тех исследований, в которых предлагается больше трех вариантов ответа. Кроме того, среди студентов вузов Калининградской области достаточно много приезжих, и студенческие выборки несколько отличаются по составу от выборочной совокупности при анкетировании учащихся школ в регионе. Как показывает опрос 2016 г., желание остаться в Калининградской области и связать с ней свою дальнейшую жизнь и карьеру почти в вдвое выше у местных студентов нежели у выходцев из других регионов России. Анализ полученных данных только по ответам респондентов, родившихся на территории области, показывает уже несколько иное соотношение категорий: не хотят и не собираются переезжать за рубеж после окончания вуза $39,2 \%$ опрошенных студентов-калининградцев; хотели бы уехать, но текущие обстоятельства им не позволяют $-43,8 \%$; планируют эмиграцию и уже прикладывают усилия для переезда - 17\% (Винокуров 2017: 71). Таким образом, если сравнивать ответы старшеклассников и студентов-калининградцев об их миграционных планах, то распределение выбранных позиций оказывается достаточно близким.
} 
старшеклассников. Большинство из них (57\% или 666 чел.) предполагают поступать в местные учебные заведения, находящиеся в основном в Калининграде. Главный аргумент такого выбора - близость от дома родителей и хороший уровень преподавания (51\% всех ответов). Однако здесь же отмечается отсутствие у оставшейся части выпускников школ сформированного на момент опроса решения и определенного ответа, так как они откладывают свой конкретный выбор на момент поступления с учетом, что будут подавать документы в несколько вузов в нескольких городах. Среди озвучивших такую позицию 11\% (129 чел.) включили Калининград как один из возможных вариантов и называют его как альтернативу городам: Санкт-Петербургу - 64 чел., Москве - 11 чел., другому городу России; либо другой стране, в том числе, Польше ${ }^{1}$, Германии, Литве -19 чел. (Григорьева, Мартынова 2017: 102-103).

Рассматривая миграционные намерения учащихся старших классов в контексте сложившейся миграционной ситуации в Калининградской области, можно отметить потенциальную нестабильность протекающих демографических процессов. Постоянный миграционный прирост скорее не обеспечивает увеличения объема задействованных в экономической системе трудовых ресурсов. Рост численности населения оказывается в диссонансе с экономикой области и создает дополнительные риски регионального развития (Федоров 2019: 48). Наряду с этим по результату опросов многие из молодых калининградцев настроены переехать в другой город или даже другую страну, и только около трети однозначно планируют дальнейшую жизнь в своем регионе.

\section{Миграционные планы старшеклассников провинциального региона европейской части России: Кировская область}

Согласно официальной статистике по ключевому относительному показателю, характеризующему интенсивность миграции, - коэффициенту миграционного прироста (оттока) - на текущий момент Кировская область располагается на 70 месте из 85 среди всех субъектов Российской Федерации и на 12 месте из 14 по Приволжскому федеральному округу (Численность 2020: табл. 1.10$)^{2}$, попадая в обоих случаях в нижнюю четверть списка. Это свидетельствует о том, что Кировская область вхо-

\footnotetext{
${ }^{1}$ В одной из научных работ, основанной на массовых опросах студентов и экспертных интервью, для калининградцев особенно выделены в качестве желаемых вузов для продолжения обучения вузы Гданьска и Сопота. Опираясь на опросы студентов в Калининграде, авторы подчеркивают, что в данном случае стремление молодых людей переехать в другую страну вызвано не переживаемыми трудностями и плохими перспективами развития дома, а ожиданиями найти впоследствии высокооплачиваемую и интересную работу по специальности там, где (как им кажется) она есть у всех, и обучение в университетах стран ЕС - первый шаг на этом пути. Наличие диплома, признаваемого в западных странах, воспринимается как стартовое условие успешной карьеры и жизни в целом (Зотова, Гриценко, Себениов 2018: 63).

${ }^{2}$ По коэффициенту миграционного прироста Кировская область опережает сопредельные северные регионы соседних федеральных округов: Республика Коми (СЗФО) - 85; Архангельская область (СЗФО) - 73. Однако, при этом отстает, и часто - существенно, от смежных южных и восточных субъектов Приволжского федерального округа, а также северо-западных регионов Центрального и Северо-Западного федеральных округов: Нижегородская область - 24; Республика Марий Эл - 34; Республика Татарстан - 30; Удмуртская республика - 68; Пермский край - 57; Костромская область (ЦФО) - 45; Вологодская область (СЗФО) - 61 (Численность 2020: табл. 1.10).
} 
дит в число территорий, заметно теряющих свое население в результате миграции ${ }^{1}$. В то же время, на протяжении последнего десятилетия при общем отрицательном сальдо миграции Кировская область одновременно демонстрировала определенную стабильность развития по коэффициенту миграционного прироста, без резких перепадов его значений и с преимущественно положительной тенденцией сокращения оттока населения на 1000 человек, что несколько смягчает ситуацию². Следует также отметить существенные различия в движении городского и сельского населения Кировской области: по городам преимущественно наблюдается миграционный прирост, который в целом держится на уровне среднего миграционного прироста по России; при этом в сельских поселениях идет массовый отток жителей с фактически самой высокой интенсивностью среди всех сельских территорий в нашей стране 3 .

Основная часть миграций в Кировской области представляет собой перемещение населения внутри России; на зарегистрированные международные переезды в среднем за последние пять лет приходится порядка 3,5\% по числу прибывших и $3 \%$ по числу выехавших за пределы области (Численность 2016-2020). Анализ ключевых направлений межрегиональных миграционных потоков, к которым относится около трети всех переселений по Кировской области, позволяет выделить следующие значимые регионы выезда кировчан: Москва и Московская область; Санкт-Петербург; Республика Коми; Республика Татарстан; Республика Марий Эл, Нижегородская область. Встречное передвижение российских граждан с целью продолжительного проживания в Кировской области во многом связано с этими же регионами; из них наиболее часто

${ }^{1}$ Обозначенная проблема не является новой для Кировской области, поскольку в ХХ веке миграционная убыль населения наблюдалась в регионе с некоторой периодичностью регулярно: отмечалась в послевоенные годы; наиболее интенсивно проявлялась в 1960-1970-е в результате массового переезда сельских жителей; несколько снизилась по масштабам в 1980-е. В период 1990-х число приехавших в Кировскую область мигрантов начинает превышать число выбывших за ее пределы кировчан, что во многом было связано с вынужденной и возвратной миграцией из стран СНГ и регионов Севера (Чернышев 2014: 51). С 2000 года вновь утвердилась тенденция миграционного оттока населения из области (Кировская 2005: 30; Кировская 2011: 29); с 2010 по 2015 годы миграционная убыль населения в Кировской области превышала естественную (Кировская 2015: 16; Кировская 2019: 23), в последние пять лет в 2015-2019 гг. находится на уровне 2,8-4,7 тыс. человек в год (Численность 2016-2020).

2 При сравнении с соседними регионами за последние десять лет схожая с Кировской областью стабильность развития по коэффициенту миграционного прироста с положительной тенденцией сокращения оттока населения присутствует только в Республике Марий Эл, где общая ситуация по этому вопросу несколько лучше, и в 2019 году впервые за долгое время отмечается миграционный прирост. Только в двух из девяти прилегающих к Кировской области административно-территориальных субъектах РФ - в Нижегородской области и в Республике Татарстан - суммарное число прибывших за последние десять лет мигрантов превышает общее число выбывших жителей региона, но в обоих случаях наблюдается постепенное снижение коэффициента миграционного прироста, и в Нижегородской области этот показатель дважды достигал отрицательных значений. На близлежащих территориях с менее интенсивным оттоком населения на 1000 человек, чем в Кировской области - Пермском крае, Вологодской области, Костромской области, Республике Удмуртия - масштабы выбытия меняются более резко, особенно в Костромской области, и, за исключением Удмуртии, также характеризуются увеличением оттока населения. В Архангельской области и Республике Коми проблема демографического развития в связи с миграцией является сложной и стояла гораздо острее, чем в среднем по субъектам РФ, которые теряют своих жителей в процессе миграции; в обоих регионах может быть отмечена положительная тенденция сокращения оттока населения в это десятилетие, но численность выехавших с их территории мигрантов по-прежнему довольно высока (Численность 2012-2020).

${ }^{3}$ Для соседних с Кировской областью регионов характерна бо́льшая равномерность развития городских и сельских территорий по миграционному движению населения, но при этом во всех из них, за исключением Республики Марий Эл и Республики Татарстан, за последние два года отмечалась миграционная убыль как городского, так и сельского населения (Численность 2019-2020: табл. 1.10). 
звучат Республика Коми, Санкт-Петербург, Москва и Московская область, Республика Марий Эл ${ }^{1}$. При изучении возрастного состава участников межрегиональной и международной миграции за последние десять лет заметно, что по Кировской области число молодых людей среди таких мигрантов оказывается бо́льшим, чем в среднем по России: в процентном отношении представлены преимущественно когорты граждан трудоспособного возраста и моложе; одновременно жители старше трудоспособного возраста практически не присутствуют в перемещениях, выходящих за границы области ${ }^{2}$. С учетом установившегося в последние годы миграционного оттока населения это может приводить к постепенному сокращению численности молодежи в регионе.

Вопросы, связанные с миграцией молодого поколения, стоят в Кировской области весьма остро и проходят обсуждение, в том числе, в рамках совместной работы научного сообщества и местной администрации (Саралиева 2011). Вместе с тем специальных исследований по данной проблематике, как и статистических сведений, пока еще мало.

С целью анализа миграционных установок учащихся старших классов Кировской области обратимся к материалам 2018-2019 гг. ${ }^{3}$ В ходе массового анкетирования были опрошены ученики четырех школ в трех районах г. Кирова, итоговая выборка составила 156 анкет. Вопрос, направленный на описание миграционных планов, показал, что только 8\% участников опроса уверенно связывают свою дальнейшую жизнь и карьеру с Кировской областью, еще $26 \%$ затруднились при ответе на этот вопрос, $40 \%$ рассматривают варианты переезда в другой регион Российской Федерации, 21\% склонны уехать на постоянное место жительства или длительный срок в другую страну ${ }^{4}$ Все те, кто предложили свой вариант ответа, в основном в равной степени готовы к переезду внутри страны и за границу (в одном случае обрисована даже ожидаемая траектория «переехать учиться в другой регион, потом уехать работать в другую страну»), кто-то подчеркивает, что может не иметь возможностей для

${ }^{1}$ Из общего числа уехавших из Кировской области в 2018 году $18 \%$ направились в Москву и Московскую область, 8\% - в Санкт-Петербург, 7\% - в Республику Коми, 6\% - в Республику Татарстан, 6\% - в Республику Марий Эл, 5\% - в Нижегородскую область (РRО Город 2019). Данные траектории перемещения остаются наиболее востребованными уже многие годы и сохраняют свою значимость в последнее десятилетие (Кировская 2015: 63; Кировская 2019: 51).

2 За последние десять лет профиль возрастного состава мигрантов по Российской Федерации на основе межрегиональных и межстрановых перемещений населения выглядит следующим образом: в среднем за 2010-2014 гг. в трудоспособном возрасте находились 76\% мигрантов, 13\% были моложе трудоспособного возраста и 11\% - старше трудоспособного возраста; в среднем за 2015-2019 гг. - 72 \%, $17 \%$ и $11 \%$ соответственно. Этот же профиль по Кировской области заметно сдвинут в сторону молодых возрастов как для прибывших, так и для выехавших за пределы региона и по миграционному оттоку сводится к следующим цифрам: в среднем за 2010-2014 гг. в трудоспособном возрасте находились 85\% мигрантов, $14 \%$ были моложе трудоспособного возраста и 1\% - старше трудоспособного возраста; в среднем за 2015-2019 гг. - 77 \%, 17\% и 6\% соответственно (Численность 2011-2020).

${ }^{3}$ Более подробно об этом исследовании и особенностях формирования выборочной совокупности см. выше.

${ }^{4}$ В опросе принимали участие, в том числе, лицейские классы, ученики которых нацелены на поступление в ведущие университеты страны и мира. Если отбросить данные по этим анкетам, то распределение ответов будет выглядеть чуть лучше: хотели бы переехать на постоянное место жительства в другую страну $25 \%$ респондентов и в другой регион России - 29\%; затруднились с ответом - $27 \%$ учащихся; планируют остаться в Кирове - 14\%; воспользовались вариантом «другое» - 5\% опрошенных. 
переезда, либо уехал бы только на короткий период времени․․

Насколько успешно молодые люди реализуют свои миграционные планы, можно в некоторой степени представить на основании данных о траектории миграции студентов, окончивших кировские вузы в 2014 г. По сведениям о выпускниках, официально трудоустроившихся в течение календарного года после получения диплома, чуть менее $85 \%$ молодых специалистов начали свою трудовую деятельность вскоре после завершения обучения и около $40 \%$ из них - в другом регионе России. Среди наиболее значимых направлений миграции могут быть названы: Москва, где трудоустроились 26\% выпускников кировских вузов 2014 г., покинувших область; Республика Коми 19\%; Нижегородская область - 9\% (Фадеева, Софронов 2018: 112, 116).

Общая миграционная ситуация в Кировской области может быть определена как достаточно сложная. Постоянный миграционный отток населения преимущественно в молодых и трудоспособных возрастах, фиксируемый в области в последние годы, остается действующим негативным фактором демографического и, как следствие, экономического развития в регионе. Отсутствие резких колебаний по интенсивности оттока жителей и практически минимальные изменения в численности городского населения являются очень хрупким основанием для достижения состояния стабильности. Текущее исследование показало сохранение массовой стратегии молодых людей по переезду из Кировской области в другие субъекты Российской Федерации и за границу. На примере двух последовательных измерений по миграционным установкам школьников в малых городах России (Флоринская 2017: 119) можно утверждать, что отмеченная тенденция может быть критичной и может ухудшаться с течением времени.

\section{Заключение}

Согласно официальным данным государственной статистики в целом по России сальдо миграции держится в рамках положительных значений, и миграционная ситуация складывается относительно благоприятно. Однако, если рассматривать движение населения по отдельным субъектам Российской Федерации, то его результаты будут существенно отличаться. В ходе настоящего исследования для анализа территориальной специфики миграционных процессов были выбраны три принципиально разных региона: столичный - г. Москва, приграничный - Калининградская область и провинциальный регион европейской части России - Кировская область. В каждом из представленных случаев можно видеть свой уникальный набор факторов, условий и их проявлений. В столице в связи с имеющимися широкими возможностями самореализации, карьерного роста и улучшения благосостояния происходит концентрация населения и, в первую очередь, молодого. В Москву едут молодые люди со всей территории нашей страны и из-за рубежа. Но одновременно именно в столице формируется основной поток мигрантов, российских граждан, которые уезжают впоследствии за границу. Характерное эксклавное положение Калининградской области обеспечивает тесное взаимодействие региона с зарубежными странами и значительную часть постоянного притока мигрантов. Здесь же возникают и определенные риски дальнейшего развития. Наиболее критичная обстановка наблюдается в Кировской области, где уже длительное время идет отток молодого трудоспособного населения без его замещения.

\footnotetext{
${ }^{1}$ Для сравнения, соотношение категорий по студенческой группе (300 анкет) выглядит следующим образом: хотели бы переехать на постоянное место жительства в другую страну 29\% респондентов и в другой регион России - 29\%; затруднились с ответом - 26\% учащихся; планируют остаться в Кирове - $12 \%$; выбрали вариант «другое» - 5\% опрошенных.
} 
Сопоставление миграционных планов учащихся старших классов в контексте текущей региональной ситуации позволяет отметить несколько важных моментов. Первый из них касается вероятного сохранения в ближайшие годы сложившихся тенденций миграционного поведения молодежи. Все озвученные респондентами установки - на смену своего постоянного места жительства либо, напротив, желании связать жизнь со своим настоящим местопребыванием - соотносятся с данными о реальном перемещении молодых россиян для каждой из территорий. Кроме того, можно выделить некоторые различия в ответах учащихся в зависимости от региона. В наибольшей степени ориентированы на проживание в своей области молодые калининградцы (чуть менее трети), в то время как уже только четверть москвичей связывают свою дальнейшую жизнь с регионом рождения, а подавляющее большинство кировчан настроены на выезд. В свою очередь школьники Москвы в значительно большей степени рассматривают миграцию в зарубежные страны и очень редко планируют уехать в другой регион России, а для учеников кировских и калининградских школ осуществление переезда за границу или в крупный российский город довольно часто является равноценным. Впрочем, следует сказать и об общей для всех трех групп категории ответов, в которой старшеклассники свидетельствуют об отсутствии у них строгого решения по поводу будущего места проживания и трудоустройства.

\section{Источники и материалы}

IOM 2020 - World Migration Report 2020, IOM (2020). International Organization for Migration Publishing, Geneva, 2020. 477 p.

PRO Город 2019 - Назван топ-7 регионов, куда переезжают жители Кировской области / Новости 02 июля 2019 [Электронный ресурс] // Портал независимого регионального СМИ с главными новостями Кирова и Кировской области «РRО Город Киров»: [веб-сайт]. https:// progorod43.ru/amp/64765 (дата обращения: 25.10.2020).

Кировская 2005 - Кировская область в 2004 году: стат. ежегодник в 3 ч. Ч. 1: Население и социальная сфера. Киров: Тер. орган Федеральной службы гос. статистики по Киров. обл., 2005. 152 с.: ил.

Кировская 2011 - Кировская область в 2010 году: стат. ежегодник в 3 ч. Ч. 1: Население и социальная сфера. Киров: Территориальный орган Федеральной службы государственной статистики по Кировской области, 2011. 152 с.: ил.

Кировская 2015 - Кировская область в 2014 году: стат. ежегодник в 3 ч. Ч. 1: Население и социальная сфера / Территориальный орган Федеральной службы государственной статистики по Кировской области. Киров, 2015. 172 с.: ил.

Кировская 2019 - Кировская область в 2018 году: стат. ежегодник / Территориальный орган Федеральной службы государственной статистики по Кировской области. Киров, 2019. 296 с.: ил.

Международная миграция 2020 - Международная миграция / Демография. Население. Официальная статистика. [Электронный ресурс] // Федеральная служба государственной статистики (Росстат): [веб-сайт]. http://rosstat.gov.ru/folder/12781 (дата обращения: 25.10.2020).

Москва 2014 - Москва в 2000-2014 гг.: Краткий статистический справочник / Мосгорстат. M., 2014. $74 \mathrm{c}$.

Москва 2020 - Москва в 2015-2019 гг.: Краткий статистический сборник / Мосстат. М., 2020. 69 с.

Общие итоги 2020 - Общие итоги миграции населения (по потокам передвижения) / Демография. Население. Официальная статистика. [Электронный ресурс] // Федеральная служба государственной статистики (Росстат): [веб-сайт]. http://rosstat.gov.ru/folder/12781 (дата обращения: 25.10.2020).

Основы 2014 - Основы государственной молодежной политики Российской Федерации на период до 2025 года [Электронный ресурс] // Правительство России: [веб-сайт]. http:// 
static.government.ru/media/files/ceFXleNUqOU.pdf (дата обращения: 25.10.2020).

ТАСС 15 июля 2020 - Границу возраста молодежи в России планируется сдвинуть до 35 лет.

15 июля 2020. [Электронный ресурс] // Информационное телеграфное агентство России

(ИТАР-ТАСС): [веб-сайт]. https://tass.ru/obschestvo/8968473 (дата обращения: 25.10.2020).

Численность 2011-2020 - Численность и миграция населения Российской Федерации. Вып. 2011-

2020. [Электронный ресурс] // Федеральная служба государственной статистики (Росстат): [веб-сайт]. http://rosstat.gov.ru/compendium/document/13283 (дата обращения: 25.10.2020).

\section{Научная литература}

Вариавская Е.Я., Чудиновских О.С. Миграционные планы выпускников региональных вузов России // Вестник Московского университета. Сер. 6: Экономика. 2014. № 3. С. 36-58.

Вендина О.И. Города на границе: испытание этнокультурным разнообразием. Города на современных границах Российской Федерации (часть 2) // Городские исследования и практики. 2016. Т. 1. № 4. С. 7-25.

Винокуров B.B. Интеллектуальная миграция студенческой молодежи Калининградской области: ожидания и реальность // Власть. 2017. №7. С. 69-74.

Горшков M.К. (отв. ред.). Столицы и регионы в современной России: мифы и реальность пятнадцать лет спустя. М.: Весь мир, 2018. 312 с.

Григорьева Р.А., Мартынова М.Ю. Молодежь в городах Калининградской области // Исследования по прикладной и неотложной этнологии. М.: ИЭА РАН, 2017. Вып. 260. 132 с.

Емельянова Л.Л. Международная трансграничная миграция в регионе юго-восточной Балтики: факторы, структура, последствия // Балтийский регион. 2010. № 4 (6). С. 61-71.

Ермаков С.П., Никитина С.Ю. Возрастные особенности миграции в субъектах Российской Федерации в 2000-2010 гг. // Народонаселение. 2015. № 3. С. 15-29.

Зайончковская Ж.А., Иоффе Г.В. Динамика расселения в Московском регионе как отражение постсоветских трансформаций // Вопросы географии. Сб. 135: География населения и социальная география / отв. ред. А.И. Алексеев. М.: Издательский дом «Кодекс», 2013. С. 188-223.

Зимовина Е.П. Миграции и процесс трансформации полиэтничной структуры населения Калининградской области в постсоветский период // Балтийский регион. 2014. № 2 (20). C. 111-127. DOI: 10.5922/2074-9848-2014-2-7.

Зотова М.В, Гриценко А.А., Себенщов А.Б. Повседневная жизнь в российском пограничье: мотивы и факторы трансграничных практик // Мир России. 2018. Т. 27. № 4. С. 56-77. DOI: 10.17323/1811-038X-2018-27-4-56-77.

Карачурина Л.Б., Мкртчян Н.В. Возрастные особенности межрегиональной миграции населения в России // Регион: экономика и социология. 2017. № 4. С. 101-125. DOI: 10.15372/REG20170405.

Карачурина Л.Б., Мкртчян Н.В. Центры и периферия в странах Балтии и регионах Северо-Запада России: динамика населения в 2000-е годы // Балтийский регион. 2014. № 2 (20). C. 62-80. DOI: 10.5922/2074-9848-2014-2-4.

Кашницкий И.С., Мкртчян Н.В., Лешуков О.В. Межрегиональная миграция молодежи в России: комплексный анализ демографической статистики // Вопросы образования. 2016. T. 13. № 3. C. 169-203. DOI: 10.17323/1814-9545-2016-3-169-203.

Лялина А.В. Некоторые особенности внешних миграционных процессов в приморских регионах Западного порубежья России // Вестник Балтийского федерального университета им. И. Канта. Сер.: Естественные и медицинские науки. 2019. № 4. С. 57-74.

Мкртчян Н.В. Миграция в Москве и Московской области: региональные и структурные особенности // Региональные исследования. 2015. № 3 (49). С. 107-116.

Мкртчян Н.В. Миграция молодежи из малых городов России // Мониторинг общественного мнения: Экономические и социальные перемены. 2017. № 1. С. 225-242. DOI: 10.14515/ monitoring.2017.1.15.

Мкртчян Н.В. О влиянии миграции на возрастной состав населения регионов, городов и районов России // Научные труды: Институт народнохозяйственного прогнозирования РАН. 2014. Том 12. С. 381-396. 
Мкртчян Н.В., Карачурина Л.Б. Миграция и естественное движение населения городов и административных районов России в 1990-2010 гг:: ключевые факторы различий // Научные труды: Институт народнохозяйственного прогнозирования РАН. 2013. Т. 11. С. 95-114.

Саралиева 3.X. (отв. ред.). Молодежь как ресурс регионального развития: материалы Международной научно-практической конференции, 27-28 октября 2011 г. Киров: ВятГГУ, 2011. 656 с.

Семенова В.В. (отв. ред.). Социальная мобильность в России: поколенческий аспект. М.: Институт социологии РАН, 2017. 384 с.

Симонян Р.X. Миграционные настроения российской молодежи: региональный аспект // Мониторинг общественного мнения: Экономические и социальные перемены. 2017. № 6. C. 312-326. DOI: 10.14515/monitoring.2017.6.16.

Симонян Р.Х. Студенческая молодежь приграничных регионов России // Социологические исследования. 2018. № 4. С. 82-89. DOI: 10.7868/S0132162518040098.

Фадеева И.М., Софронов Д.А. Траектории межрегиональных миграций выпускников вузов Приволжского федерального округа // Известия высших учебных заведений. Поволжский регион. Общественные науки. 2018. № 1 (45). C. 108-119. DOI 10.21685/2072-3016-2018-1-13.

Федоров Г.М. (под ред.). Проблемы экономической безопасности регионов Западного порубежья России. Калининград: БФУ им. И. Канта, 2019. 267 с.

Федоров Г.М. О сценариях демографического развития Калининградской области // Вестник Балтийского федерального университета им. И. Канта. Сер.: Естественные и медицинские науки. 2017. № 3. С. 5-21.

Флоринская Ю.Ф. Выпускники школ из малых городов России: образовательные и миграционные стратегии // Проблемы прогнозирования. 2017. № 1 (160). С. 114-124.

Флоринская Ю.Ф., Рощзина Т.Г. Оценка уровня миграционной мобильности молодежи малых российских городов (по опросам выпускников школ) // Проблемы прогнозирования. 2008. № 3 (108). С. 125-139.

Чернышев К.А. Современные проблемы миграции молодежи Кировской области // Региональная экономика: теория и практика. 2014. № 48 (375). С. 48-58.

Zykina, Olga A.*

\section{Migration plans of Russian high school students: a regional dimension}

\section{DOI: $10.33876 / 2311-0546 / 2020-52-4 / 153-169$}

The migration factor can have a different impact on the socio-economic development of territories, depending on the specific conditions and established practices. Using the example of three different subjects of the Russian Federation - Moscow, Kaliningrad and Kirov regions - the article attempts to study the relationship between the migration situation in the region and the migration attitudes of the younger generation. An analysis of the specifics of migration processes, based on the results of a number of expert works and information from official state statistics over the past ten years, suggests some typical directions for the Russian population movement in each of the regions. The empirical data are based on the results of a mass survey of high school and university students. This paper presents an up-to-date cross-section of the migration intentions of high school students in the context of regional aspects of youth migration strategies, which allows for assessing the feasibility of their plans on a national scale. In general, one can talk about the likely preservation of the prevailing trends in the migration behavior of young people in the coming years. All the attitudes reported by the respondents - to change their permanent place of residence or, onthe contrary, to stay within their current place of residence - correlate with the data on the real movements of young Russians for each of the territories.

Key words: high school students; migration plans; regional specifics of migration processes; interregional migration of youth; Moscow; Kaliningrad region; Kirov region 
* Zykina, Olga A. - junior researcher, Institute of Ethnology and Anthropology RAS (Moscow, RF). E-mail: ol_ya_z@mail.ru

The research was supported by the Russian Foundation for Basic Research (RFFI, project No. 20-59-00014)

\section{References}

Chernyshev, K.A. 2014. Sovremennye problemy migratsii molodezhi Kirovskoi oblasti [The present-day problems of youth migration of the Kirov region]. Regional'naya ekonomika: teoriya i praktika 48 (375): 48-58.

Fadeeva, I.M., Sofronov, D.A. 2018. Traektorii mezhregional'nykh migratsii vypusknikov vuzov Privolzhskogo federal'nogo okruga [Interregional migration trajectories of high schools graduates in Volga federal district] Izvestiya vysshikh uchebnykh zavedenii. Povolzhskii region. Obshchestvennye nauki 1 (45): 108-119. DOI 10.21685/2072-3016-2018-1-13.

Fedorov, G.M. 2017. O stsenariyakh demograficheskogo razvitiya Kaliningradskoi oblasti [Demographic development scenarios for the Kaliningrad region]. Vestnik Baltiiskogo federal'nogo universiteta im. I. Kanta. Ser.: Estestvennye i meditsinskie nauki 3: 5-21.

Fedorov, G.M. (ed.). 2019. Problemy ekonomicheskoi bezopasnosti regionov Zapadnogo porubezh'ya Rossii [Problems of economic security of the Western border regions of Russia]. Kaliningrad: BFU im I. Kanta.

Florinskaya, Yu.F. 2017. Vypuskniki shkol iz malykh gorodov Rossii: obrazovatel'nye i migratsionnye strategii [School graduates from small towns in Russia: educational and migration strategies]. Problemy prognozirovaniya 1 (160): 114-124.

Florinskaya, Yu.F., Roshchina, T.G. 2008. Otsenka urovnya migratsionnoi mobil'nosti molodezhi malykh rossiiskikh gorodov (po oprosam vypusknikov shkol) [Estimating the migratory mobility of the youth living in small Russian towns: a school leavers' interview]. Problemy prognozirovaniya 3 (108): 125-139.

Gorshkov, M.K. (ed.). 2018. Stolitsy i regiony v sovremennoi Rossii: mify i real'nost'pyatnadtsat'let spustya [Capitals and regions in modern Russia: myths and reality fifteen years later]. Moscow: Ves' mir.

Grigorieva, R.A., Martynova, M.Y. 2017. Molodezh'v gorodakh Kaliningradskoi oblasti [Youth in the cities of the Kaliningrad region]. Issledovaniya po prikladnoi i neotlozhnoi etnologii 260. Moscow: IEA RAN.

Karachurina, L.B., Mkrtchyan, N.V. 2014. Tsentry i periferiya v stranakh Baltii i regionakh SeveroZapada Rossii: dinamika naseleniya v 2000-e gody [The Baltics and Russian North-West: the core and the periphery in the 2000s]. Baltiiskii region 2 (20): 62-80. DOI: 10.5922/2074-9848-2014-2-4.

Karachurina, L.B., Mkrtchyan, N.V. 2017. Vozrastnye osobennosti mezhregional'noi migratsii naseleniya $\mathrm{v}$ Rossii [Age specific of interregional migration in Russia]. Region: ekonomika $i$ sotsiologiya 4 (96): 101-125. DOI: 10.15372/REG20170405.

Kashnitskiy, I.S., Mkrtchyan, N.V., Leshukov, O.V. 2016. Mezhregional'naya migratsiya molodezhi v Rossii: kompleksnyi analiz demograficheskoi statistiki [Interregional migration of youths in Russia: a comprehensive analysis of demographic statistics]. Voprosy obrazovaniya 13 (3): 169-203. DOI: 10.17323/1814-9545-2016-3-169-203.

Lialina, A.V. 2019. Nekotorye osobennosti vneshnikh migratsionnykh protsessov v primorskikh regionakh Zapadnogo porubezh'ya Rossii [Some features of external migration processes in the coastal regions of the Western borderlands of Russia]. Vestnik Baltiiskogo federal'nogo universiteta im. I. Kanta. Ser.: Estestvennye i meditsinskie nauki 4: 57-74.

Mkrtchyan, N.V. 2014. O vliyanii migratsii na vozrastnoi sostav naseleniya regionov, gorodov i raionov Rossii [To the degree of migration influence on the population age structure in Russian regions, tows and districts]. Nauchnye trudy: Institut narodnokhozyaistvennogo prognozirovaniya RAN 12: 381-396.

Mkrtchyan, N.V. 2015. Migratsiya v Moskve i Moskovskoi oblasti: regional'nye i strukturnye osobennosti [Migration in Moscow and Moscow region: regional and structural peculiarities]. Regional'nye issledovaniya 3 (49): 107-116.

Mkrtchyan, N.V. 2017. Migratsiya molodezhi iz malykh gorodov Rossii [The youth migration from small towns in Russia]. Monitoring obshchestvennogo mneniya: Ekonomicheskie i sotsial'nye 
peremeny 1: 225-242. DOI: 10.14515/monitoring.2017.1.15.

Mkrtchyan, N.V., Karachurnia, L.B. 2013. Migratsiya i estestvennoe dvizhenie naseleniya gorodov i administrativnykh raionov Rossii v 1990-2010 gg.: klyuchevye faktory razlichii [Migration and natural movement of the population of cities and administrative regions of Russia in 1990-2010: key factors of differences]. Nauchnye trudy: Institut narodnokhozyaistvennogo prognozirovaniya RAN 11: 95-114.

Saralieva, Z.K.-M., ed. 2011. Molodezh' kak resurs regional'nogo razvitiya: materialy Mezhdunarodnoi nauchno-prakticheskoi konferentsii, 27-28 oktyabrya $2011 \mathrm{~g}$. [Youth as a resource for regional development: materials of the International scientific and practical conference, October 27-28, 2011]. Kirov: VyatGGU.

Semenova, V.V., ed. 2017. Sotsial'naya mobil'nost'v Rossii: pokolencheskii aspect [Social mobility in Russia: generational dimension]. Moscow: Institut sotsiologii RAN.

Simonyan, R.H. 2017. Migratsionnye nastroeniya rossiiskoi molodezhi: regional'nyi aspekt [Migration attitudes of Russian youth: a regional dimension]. Monitoring obshchestvennogo mneniya: Ekonomicheskie $i$ sotsial'nye peremeny 6: 313-326. DOI: 10.14515/ monitoring.2017.6.16.

Simonyan, R.H. 2018. Studencheskaya molodezh' prigranichnykh regionov Rossii [Student youth of the border regions Russia]. Sotsiologicheskie issledovaniya 4: 82-89. DOI: 10.7868/ S0132162518040098.

Varshavskaya, E.Ya., Chudinovskikh, O.S. 2014. Migratsionnye plany vypusknikov regional'nykh vuzov Rossii [Migration intentions of graduates of Russia's regional higher educational institutions]. Vestnik Moskovskogo universiteta. Ser. 6, Ekonomika 3: 36-58.

Vendina, O.I. 2016. Goroda na granitse: ispytanie etnokul'turnym raznoobraziem. Goroda na sovremennykh granitsakh Rossiiskoi Federatsii (chast' 2) [The cities on the border: the ethnocultural diversity test. The cities on the border of the russian federation. (Part 2)]. Gorodskie issledovaniya i praktiki 1 (4): 7-25.

Vinokurov, V.V. 2017. Intellektual'naya migratsiya studencheskoi molodezhi Kaliningradskoi oblasti: ozhidaniya i real'nost' [Intellectual migration of students of Kaliningrad region: expectations and reality]. Vlast'7: 69-74.

Yemelyanova, L.L. 2010. Mezhdunarodnaya transgranichnaya migratsiya v regione yugovostochnoi Baltiki: faktory, struktura, posledstviya [International cross-border migration in the south-east Baltic: factors, structure, consequences]. Baltiiskii region 4 (6): 61-71.

Yermakov, S.P., Nikitina, S.Y. 2015. Vozrastnye osobennosti migratsii v sub"ektakh Rossiiskoi Federatsii v 2000-2010 gg. [Age specifics of migration in the Russian Federation subjects during 2000-2010]. Narodonaselenie 3: 15-29.

Zayonchkovskaya, Zh.A., Ioffe, G.V. 2013. Dinamika rasseleniya v Moskovskom regione kak otrazhenie postsovetskikh transformatsii [The dynamics of settlement in the Moscow region as a reflection of the post-Soviet transformations]. In Voprosy geografii. Sb. 135: Geografiya naseleniya $i$ sotsial'naya geografiya [Geography issues. Dig. 135: Geography of population and social geography], edited by A.I. Alekseev, 188-223. Moscow: Izdatel'skii dom «Kodeks».

Zimovina, E.P. 2014. Migratsii i protsess transformatsii polietnichnoi struktury naseleniya Kaliningradskoi oblasti v postsovetskii period [Migration and the transformation of multiethnic population structure in the Kaliningrad region of the post-soviet era]. Baltiiskii region 2 (20): 111-127. DOI: 10.5922/2074-9848-2014-2-7.

Zotova, M.V., Gritsenko, A.A., Sebentsov, A.B. 2018. Povsednevnaya zhizn' v rossiiskom pogranich'e: motivy i faktory transgranichnykh praktik [Everyday life in the Russian Borderlands: the motives and determinants of cross-border practices]. Mir Rossii 27 (4): 56-77. DOI: $10.17323 / 1811-038 X-2018-27-4-56-77$. 